\title{
NURSING PERCEPTIONS ABOUT ABORTION MANAGEMENT AND CARE: A QUALITATIVE STUDY
}

\author{
Ivanete da Silva Santiago Strefling ${ }^{1}$, Wilson Danilo Lunardi Filho², Nalú Pereira da Costa Kerber ${ }^{3}$, Marilu \\ Correa Soares ${ }^{4}$, Juliane Portella Ribeiro ${ }^{5}$
}

\begin{abstract}
${ }^{1}$ Doctoral student, Programa de Pós-graduação em Enfermagem at Universidade Federal de Pelotas (UFPel). Pelotas, Rio Grande do Sul, Brazil. E-mail: ivanete25@gmail.com

2 Ph.D. in Nursing. Professor, Departamento de Enfermagem, Universidade Federal do Rio Grande (FURG). Rio Grande, Rio Grande do Sul, Brazil. E-mail: lunardifilho@terra.com.br

${ }^{3}$ Ph.D. in Nursing. Professor, Departamento de Enfermagem, FURG. Rio Grande, Rio Grande do Sul, Brazil. E-mail: nalu@vetorial.net

${ }^{4}$ Ph.D. in Nursing. Professor, Departamento de Enfermagem, UFPel. Pelotas, Rio Grande do Sul, Brazil. E-mail: enfmari@uol.com.br

${ }^{5}$ Doctoral student, Programa de Pós-graduação em Enfermagem, FURG. Rio Grande, Rio Grande do Sul, Brazil. E-mail: ju_ ribeiro1985@hotmail.com
\end{abstract}

\begin{abstract}
This study aimed to describe management and implementation of care for women hospitalized due to an abortion, from the perspective of nursing professionals. A qualitative study performed in an obstetric hospital unit of a University Hospital in the extreme South of Brazil, by means of a semi-structured interview with 19 nursing professionals. For the analysis, the Collective Subject Discourse technique was used. The statements were ambivalent. Some nursing professionals reported interference in discriminatory behavior and little interaction with the woman, resulting in care being organized with a focus on clinical aspects. Others considered care to be appropriate, regardless of the etiology of abortion, pointing out some humanized initiatives such as emotional support and provision of a private therapeutic environment. This research broadens the range of information about the management and implementation of care for women hospitalized due to abortion, highlighting the importance of articulating perceptions, feelings and ethical behavior with actions to plan, manage and provide care.
\end{abstract}

DESCRIPTORS: Abortion. Nursing care. Health management. Health policy.

\section{PERCEPÇÕES DA ENFERMAGEM SOBRE GESTÃO E CUIDADO NO ABORTAMENTO: ESTUDO QUALITATIVO}

RESUMO: Objetivou-se descrever a gestão e realização do cuidado às mulheres hospitalizadas por abortamento sob a perspectiva dos profissionais de enfermagem. Estudo qualitativo, realizado na unidade de internação obstétrica de um hospital universitário do extremo sul do Brasil, por meio de entrevista semiestruturada com 19 profissionais de enfermagem. Para análise, utilizou-se a técnica do Discurso do Sujeito Coletivo. Os discursos mostraram-se ambivalentes. Alguns profissionais de enfermagem referiram que há interferência do comportamento discriminatório e pouca interação com a mulher, resultando na organização do cuidado focado nos aspectos clínicos. Outros consideraram o atendimento bom, independentemente da etiologia do aborto, apontando algumas iniciativas humanizadas como apoio emocional e provisão de um ambiente terapêutico privativo. Esta pesquisa amplia o leque de informações acerca da gestão e realização do cuidado às mulheres hospitalizadas por abortamento, destacando a importância de articular percepções, sentimentos e comportamento ético com ações de planejar, gerenciar e cuidar.

DESCRITORES: Aborto. Cuidados de enfermagem. Gestão em saúde. Política de saúde.

\section{LAS PERCEPCIONES DE ATENCIÓN DE ENFERMERÍA EN ABORTO Y GESTIÓN: ESTUDIO CUALITATIVO}

\begin{abstract}
RESUMEN: Este estudio tiene el objetivo de describir la gestión y realización de las mujeres hospitalizadas por abortamiento bajo la perspectiva de los profesionales de enfermería. Estudio cualitativo, llevado a cabo en una unidad de Obstetricia del hospital universitario en el extremo sur de Brasil, mediante una entrevista semiestructurada con 19 profesionales de enfermería. Para el análisis, se utilizó la técnica del discurso sujeto colectivo. Los discursos eran ambivalientes. Algunos profesionales de la enfermería, comentaron que hay interferencia de un comportamiento discriminatorio y poca interacción con la mujer, resultando en la organización de la atención se centró en aspectos clínicos. Otros consideraron buena asistencia, independientemente de la etiología del aborto, señalando algunas iniciativas humanizadas como apoyo emocional y la provisión de un ambiente terapéutico privado. Esta investigación amplía la gama de información sobre la gestión y realización del cuidado con las mujeres hospitalizadas por abortamiento, poniendo de relieve la importancia de articular las percepciones, sentimientos y comportamiento ético con acciones para planificar, administrar y cuidar.
\end{abstract}

DESCRIPTORES: Aborto. Atención de enfermería. Gestión en salud. Política de salud. 


\section{INTRODUCTION}

Abortion raises heated discussions in society as a whole. Still widely practiced, it is a complex challenge for health care professionals, because it is an extreme situation involving matters of life and death. With the maintenance of restrictive legislation or illegality in many countries, many women, due to unplanned or unwanted pregnancies, are submitted to unsafe practices to terminate a pregnancy, which makes this condition an underlying cause of nearly $13 \%$ of maternal deaths. ${ }^{1}$ The Report on the Situation of the World Population $^{2}$ estimated that in 2012, or up to 2012, around 80 million unwanted pregnancies would occur and that 40 million of them would probably end in abortion. In Brazil, just in 2008, there were 215,000 SUS hospital admissions for abortion complications, out of which only 3230 were legal. ${ }^{3}$

With the goal of changing this scenario, in recent decades the United Nations has promoted several world conferences to discuss the issue of women's health, including sexual and reproductive rights as human rights. During the conference, which took place in Cairo in 1994 and Beijing in 1995, and in accordance with the millennium goal of reducing three-quarters of maternal mortality between 1990 and 2015, the governments of the participating States committed to providing quality care to all women, so that they are able to exercise these rights and achieve universal access to reproductive health by 2015 . However, achieving this goal depends on the effectiveness of public health care policies for women. ${ }^{4}$

In Brazil, abortion is considered a public health issue that must be addressed collectively, both for spontaneous and induced abortion. That leads the discourse beyond morality and legality, enabling the debate in the spaces of health care services, among managers and professionals, not only in the context of public health, but also in the hospital environment. ${ }^{5}$

Based on this understanding, the Technical Normative for Humane Care for Abortion (NTAHA) was published in 2005, and revised in 2011, containing guidelines to assist professionals and health care services in ensuring the human rights of women, including their sexual and reproductive rights. This Normative proposes welcoming, instruction and clinical attention for the female user, trying to establish a trusting relationship, setting aside judgment, discrimination, moral and religious precepts, respecting ethics, autonomy and the woman's decision-making ability. ${ }^{6}$
At the hospital, where women with complications related to both types of abortion usually go, planning how to apply these guidelines is a process of care management. In nursing, care management consists of direct and indirect actions, the nurse's main function being to organize and coordinate care activities, and facilitate the resources, whether material, human and/or organizational in nature, for the other nursing team professionals and health care staff to act.?

However, to offer systematic and quality care to women hospitalized for abortion, it is necessary to articulate theoretical and practical knowledge, and to have communication and interaction skills, always considering women as care subjects and their needs as action-guiding. ${ }^{6,8}$

By analyzing the scientific literature on the subject, it was found that few studies have addressed the management and implementation of care for women hospitalized for abortion from the perspective of nursing professionals. ${ }^{5,9}$ The vast majority of publications are about women's perceptions of received care. ${ }^{10-12}$

Nursing care management is a tool for the care process. The quality of care consists in constant exchange of information, ideas and perceptions among workers, thereby contributing to the development of coordinated actions by minimizing the differences and approaching members of the nursing team with a view towards the same aim. ${ }^{8}$ Given the above, this study aimed to describe care management and implementation for women hospitalized for abortion, from the perspective of nursing professionals.

\section{METHOD}

This is a qualitative, exploratory-descriptive study, because it enabled deepening knowledge on the subject under investigation, and the exposure of the perceptions and opinions of the research subjects about their experienced reality. ${ }^{13}$ The place of study was the obstetric inpatient unit of a public hospital in southern Rio Grande do Sul State.

Nineteen nursing professionals who cared for women hospitalized for abortion were subjects of this study (seven nurses and 12 nursing technicians), who spontaneously accepted contributing to this research by signing the Terms of Free and Informed Consent, and authorizing the recording of interviews. The total number of participants was defined by the number of interviews that enabled reaching the understanding of the studied 
phenomenon, characterized by the repetition of content. Participants were identified by the initials of the professional category, in addition to the sequenced number of the interview, e.g., nurse (N1; NE2) and nursing technician (NT3; NT4).

Data were collected by mean of a semi-structured interview, containing the question: How do you perceive the nursing care management and implementation that is provided to women admitted for abortion? The interviews took place during November of 2012. The interviews were recorded, and soon after were fully transcribed.

Data were analyzed and interpreted according to the Discourse of the Collective Subject (DCS) method, which made it possible to reconstruct the synthesized statements deemed necessary to express the collective thought of the participants regarding the investigated phenomenon, with different excerpts of individual statements, as in a puzzle. ${ }^{14}$

Initially the interviews were transcribed verbatim. Then the individual lines, excerpts or verbatim transcripts of the statements containing the essence of the statement, the discursive content, called Key-Expressions K (KE) were underlined. The Central Ideas (CI) were highlighted in the key-expressions, i.e. names or linguistic expressions accurately and reliably describing the meaning of each of the analyzed statements. The central ideas with the same meaning found in the individual statements were united, forming a central synthesis idea with all the key-expressions related to them. These key-expressions were organized in a sequence to later constitute the DCS. ${ }^{14}$ Every step was inserted into the Discourse Analysis Instrument (DAI1), consisting of columns and containing key expressions, central ideas and central synthesis idea.

Afterwards, the construction of DCS was initiated with a new Speech Analysis Instrument (IAD2); the central synthesis idea, which contained the grouping of key-expressions of their central ideas, composed two columns in the IAD2. The first column contained the grouped key-expressions, and the second column contained the DCS that was constructed with them. With the sequence of the key-expressions excerpts, connectors were added to unite them, obeying a coherence, with a statement beginning, middle and end. In this construction process, it was necessary to deconstruct the statement, starting from the more general and moving to the more specific. Finally, repetitions of ideas and particularities of individual statements were eliminated for structuring of the Discourse of the Collective Subject.

The ethical aspects were abided by, according to Resolution 466/12 of the National Health Council. The project was approved by the Research Ethics Committee at Universidade Federal do Rio Grande, Protocol n. 101/ 2012.

\section{RESULTS}

Of the 19 subjects in this study, one was male. The age of participants ranged from 24 to 64 years. The time of work as a professional was six months to 45 years. The period of professional work experience was not limited, so that the similarities and/or differences of statements regarding the theme were known.

In the interpretation phase, data regarding care management and implementation for women hospitalized for abortion from the perspective of nursing professionals acting in the obstetric inpatient unit of the hospital were grouped by categories of Central Ideas, which will be presented below in the form of DCS.

\section{CI - Care Management/Implementation influenced by value judgment}

In this $\mathrm{CI}$, the respondents perceived that both care management and implementation were deficient because, due to preconceptions, not all professionals felt prepared and comfortable to interact.

DCS - I think it's deficient because it's an issue that involves value judgments. People pre-judge. When it's induced, there is a certain rejection, which is expressed by comments such as: 'Ah! Has she induced an abortion? Now, I will set her aside.' Otherwise, the treatment is like any other. But overall scope, it depends on how it went. It's not very good. I speak for myself: when it was provoked, I cannot smile a lot and care is implemented according to what the person thinks of it. Then you have to be very careful dealing with this situation. We don't go too deep in the subject. We provide care, but we don't ask too much, because we believed that this woman is not ready to talk. It isn't a discrimination not taking care of the patient, but you are afraid of how you talk. I realize that although care itself is the same for all patients, many professionals have different treatment when in situations of abortion. They are not prepared to talk (N2, NT3, NT4, N6, N12).

In these DCS, the conflicts of values and lack of professional qualification are seen as reasons for 
care fragmentation. Thereby, the worker performs only technical procedures and is silent when facing the woman, missing an opportunity to create a connection and an empathetic relationship that fosters the provision of required information for the woman, as the subject of health care action, to conduct the processes of care action, decisionmaking and self-care.

Personal values are important, but health care professionals must separate personal beliefs from professional practices, because workers' attitudes towards the women have considerable weight. Positive encounters tend to increase women's satisfaction and make them more likely to trust the professional and seek care in case of future health problems. ${ }^{6}$

In addition to discrimination and value judgment, the respondents pointed out the difficulty of communication and interaction during care. As discussed in the following CI, the worker/user interpersonal relationship is influenced by cultural and socioeconomic differences.

\section{CI - Care Management/Implementation influenced by sociocultural aspects}

DCS - I feel that there is an embarrassment in general. Those patients sometimes are not very cooperative. They are reluctant to receive medication, are rebelious, arrive at the service disturbed, want to leave, all of a sudden they flee from the hospital and we are in a difficult situation as care managers. Regarding the relationship with the team, it depends on the educational level of each patient, the community where they come from... There are many patients who get angry. Because they are angry, when something happens, they dump it on whoever is around. There are also those people who induce abortion, and regret it later. Some are religious and believe that they will pay for it. Others have induced it due to financial issues. So, the biggest difficulty is that sometimes we don't know how to use the correct expression. We can't say, Oh! You did it, and now will regret it, why? Regretting is part of being human. Sometimes it is not provoked. Then they cry, they feel very sad about the lost baby, get sadder and sadder, depressed. It's difficult! In both situations. Other than that, talking is complicated, when there is a family member around, because they are often terrified that the family members will know that it was a provoked abortion. You never know what the patient told the family. You will reveal things there, and you don't know what the family knows about this truth (N1, NT2, NT5, NT11, N17).
In Brazil, as in other developing countries, where the highest rates of unplanned pregnancies occur and where there is no access to safe abortion, the most vulnerable women are those living in poverty and with limited access to information and education. This socioeconomic vulnerability can generate low self-esteem in women, a predisposing factor for exposure to risky health situations. ${ }^{10,12}$ The notion of illegality, for most abortion situations, can also be linked to the unsociable behavior of users, even when the abortion has been spontaneous, because sometimes they fail to notice from the professional the friendly care that they need.

The content exposed in the two DCSs above corroborate the results of other studies ${ }^{10-12,15}$ about the problems faced by health service users, including difficulties in hospitalization, lack of information on interventions to be performed, disregard for the needs of women and their ability to share decisions, even situations of discrimination that they have suffered during hospitalization.

According to a study that aimed to identify the knowledge of health care professionals regarding the Brazilian legislation on abortion, $7.5 \%$ of nurses said they do not know the law. ${ }^{16}$ The lack of knowledge of health care professionals on legislation and ethical aspects related to abortion tends to encourage discriminatory, punitive and prescriptive assistance. ${ }^{6,17}$ This deficiency, in addition to leading to difficulty with law enforcement, also interferes with the quality of planning and execution of care for patients who had an abortion in the hospital and health care services, as reported by the participants of this study.

Because the nurses' duties are to plan, coordinate, assist and educate, compliance with the recommendations of the Ministry of Health, as described in NTAHA, depends on the organization of the work process. Therefore, it is a prerogative of the nurse to combine theoretical knowledge with practical activities, disseminate information on the laws in force for workers and users; provide technical, scientific and humanistic training to the nursing staff, thereby enabling the use of appropriate therapeutic measures and the use of appropriate technologies for safe, qualified and humane treatment, as recommended by the World Health Organization. ${ }^{1,16}$

Another issue pointed out in the last DCS refers to family relationships. Most often, women face the abortion situation alone, either because they were abandoned by the partner and/or fam- 
Strefling ISS, Lunardi Filho WD, Kerber NPC, Soares MC, Ribeiro JP

ily of origin, or because, by personal decision, they chose to terminate the pregnancy, assuming the right to decide over their bodies. ${ }^{17}$ However, in some cases, the women's feeling after abortion is relief, but also shame, because this is socially an act that injures morale. Therefore they fear being judged by people in their social context, by health care professionals, and their own families. ${ }^{18}$

However, when the opposite happens (when the user is accompanied), the participants mentioned this fact as an obstacle to interaction, because they are afraid of impairing the relationship between the professional and the woman and/or between the user and companion, as they do not know how much the partner knows about what happened. In this case, it is the nursing staff's duty to use active listening, thereby giving space and confidence so the women can break the silence and talk about their experiences. ${ }^{5}$

The nursing professionals need to think, speak and act in the most neutral way possible during clinical interactions, and adapt their behavior and language, according to the clues provided by the women. ${ }^{17}$ This is an important time for the professional to know the social context and the health situation of the woman and, from there, to formulate a plan of action, according to the identified demand, fulfilling the proposals of the humanizing policies. The results exposed so far reinforce that sensitivity and communication skills are essential tools in the nursing work management process, with which one can transform the individual and collective conscience, articulate theory and practice, and qualify the actions of the team. ${ }^{7}$

However, the reality expressed by the participants and confirmed by other authors demonstrates that the presence of several obstacles has impaired the transformation of this vertical model. In this study, some statements make it clear that vocational training leads to management of care provided to women, which often results in practices aimed only to meet clinical needs, as in the following DCS:

\section{CI - Care Management/Implementation focused on clinical care}

DCS - First of all, we pay attention to risks to the patient's life. We provide all practical care, check the vital signs. During this assessment, we'll,see whether the cervix is open, whether she is bleeding. If it's an advanced pregnancy, we can get an ultrasound to check for the baby's heart beat. The first care given are those, part of the daily routine. When the abortion was provoked, we have to keep watch and see whether she expelled the baby and if the cervix is closing (NT2, NT8, NT10, N17, NT18, NT19).

In general, during health care practices, it is the nursing professionals' role to address two basic aspects. The first is to preserve, respect and recognize the particularity, individuality and variability of situations and users' needs. The second aspect is to comply with certain rules, regulations and general values. To account for these aspects, the nursing professionals need to be consciously integrated into various relational and interactive spaces, targeted to the specific needs of women so that they are cared for humanely and comprehensively. ${ }^{19}$

Following this path, in the next DCS, the nursing professionals expose a positive view about the management and implementation of care provided to women hospitalized due to abortion complications.

\section{CI - Care Management/Implementation for women that had an abortion is in accordance with the integrative and humane care model}

DCS - I think care is good, it's pretty easy. It's quite different from before, when professionals were more resistant, they acted colder. I've worked in the emergency room, where we admitted people, started an $I V$, took them to curettage, and they were discharged home and no one cared. So I think care here is very good. There's no special care, but we try to provide maximum safety for them in the physical and psychological aspects. We talk to them, perform technical procedures and provide support. When an abortion was provoked, some are not very concerned and some are crushed. For these, we try to provide greater psychological support: hang around, talk, listen. Sometimes they cry a lot. Sometimes they don't want our presence, sometimes they want attention. Then you have to be very careful dealing with this situation. If we notice that things are getting serious, the patient is getting very depressed, we call a psychologist to get involved, to have a deeper conversation which we can't. Those that didn't provoke the abortion want care because it's like a dream gone away. Usually, they open up and tell us what happened (N1, NT3, N5, NT7, NT11, NT13, NT16, N17).

This $\mathrm{CI}$ underlies the affirmative that there are health care professionals who recognize the problem and assume that care should not be influenced by the etiology of abortion, because it 
is about human relationships, and regardless of the act, the woman deserves to be treated with dignity. ${ }^{16}$

The content of this DCS was also reported in another study, in which women considered care received during hospitalization adequate to their needs, which helped make them feel welcomed and safe. ${ }^{12}$ However, women with negative experiences of previous hospitalizations think they will be treated badly because they had an abortion. When specific episodes are not confirmed, they feel surprised at the quality of care and tend to positively evaluate the service, favoring the restoration of physical health and the possibility of resumption of everyday life, especially considering the long journey that many have experienced. ${ }^{10}$

Because the issue of abortion sometimes is accompanied by psychological and mental disorders, some interviewed professionals working in the two studied units highlighted the psychological support, dialogue, and listening as initiatives that favor humanizing care, regardless of the etiology of the abortion.

Sustaining these statements, authors of a recent study point out that mental problems can arise as a result of abortion, regardless of whether the loss was caused or natural. Therefore, they state that the identification of early signs and symptoms will enable user referral to a qualified professional, avoiding major suffering. ${ }^{20}$

From the perspective of integrative and humanized care, communication is part of the treatment, a key tool in nursing care for the woman who is frail due to the abortion process.

On the other hand, regarding the care process, there were participants who considered it easy to assist women who had had abortions because they believed that they are more accessible and are only a little or not at all demanding:

\section{CI - Care Management/Implementation: easy, non-demanding women}

DCS - For me it's easy because I have worked extensively with women. I have the view that everyone does whatever one feels like. It's your life and I'm not here to judge, just to assist. I think it's easy to care because I love to talk. I talk here, there, and they are in their corner. They are not hard work, do not demand anything from you; however, they establish limits and when I realize it, I stop there. Often, they are open, ask to talk, say they have asked for a sterilization but they won't do it, and there's nothing you can do about it because it is a bureaucracy. Now, when abortion was spontaneous, they are more tearful, upset because they wanted the pregnancy, but these are easy to reach, they open up and we give advice (TE3, TE6, TE7, TE19).

This statement, at first, seems to reflect that care is planned, managed and executed according to what is recommended by the Ministry of Health in NTAHA. However, because women do not have much expectation about the quality of care, they may be cornered, not interact, and be content with targeted care practices aimed especially at the resolution of biological needs, as in the hegemonic care model.

As an expression of discriminatory behaviors, the participants pointed out that in cases of spontaneous abortions, the relationship is easier, because women more easily express themselves, staff welcoming and instructions occur more naturally. This can be understood as a cultural reflection, in which both women and professionals feel safe because they are not violating any legal or moral standard.

As for the organization of the unit, in the next $\mathrm{CI}$, the nursing professionals pointed out that having a specific room or ward for women having an abortion is a prioritized aspect in the management of the service, both due to the issue of privacy and to avoid cross-infection. However, this situation is not always possible due to overcrowding.

\section{CI - Ambience of the Obstetric Inpatient Unit}

DCS - Here, it's pretty calm. One thing that we prioritize when organizing the service, it's not leaving pregnant women or postpartum women with those who had an abortion because you never know. I mean, sometimes you even know you can cause suffering, increase the grief of the mother who lost her baby due to her staying with a mother who is breastfeeding. As some have natural abortions and other induce it, we try to prevent it so that they are not traumatized. But when the wards are very crowded, the tendency is to put HIV-positive mothers who are not breastfeeding along with those who had an abortion. But we always prioritize a small unit just for abortion cases, both to avoid embarrassment but also due to the issue of infection (N2, N6 NT10, N12, N17).

According to the Ministry of Health, a cozy, private space promotes a feeling of comfort, provides professional/user interaction, helps in the development of feelings, reduces the length of hospital stay, while enabling conduct by health 
care professionals that is closer to the reality of the woman's needs. ${ }^{21}$ It also serves as a facilitating tool for the work process, because it promotes the optimization of resources, increases the workers' well-being, and contributes to the reduction of costs. ${ }^{12}$

Therefore, humanizing of nursing services involves the organization of these units, adapting them as cozy and comfortable environments that emphasize privacy and the use of communication skills for the realization of comprehensive care, provided by qualified professionals committed to quality and effectiveness of care for women hospitalized for abortion.

\section{CONCLUSION}

The statements of the nursing professionals about management and implementation of care for women hospitalized for abortion showed an ambivalent view in relation to their practices. On the one hand, the statements leave implicit the interference of discriminatory behavior and little professional interaction with the woman, resulting in the service organization focused on clinical aspects and fragmentation of care.

On the other hand, in other categories of DCS, some of the nurses recognized the importance of providing dignified, humane treatment, regardless of the etiology of abortion, and pointed to some humanized aspects such as listening, psychological support and the provision of a unique therapeutic environment separated from other patients in order to improve care.

However, to achieve the goal of all women having their sexual and reproductive rights guaranteed, nursing professionals must broaden their view of the factors surrounding the abortion process. Therefore, it is necessary that the nursing manager and his/her team remove stereotypes in the social culture, when it comes to abortion, and consider the subjectivity of every woman to plan and implement care.

These views must be addressed both during professional education and during continued qualification of the team so that, when faced with situations of abortion, they do not feel apprehensive, not knowing how to act about the problem, and lose the opportunity to interact and clarify any doubts of the women and/or the family.

The result of this study can expand the range of information available to nursing managers/staff about the care to women hospitalized for abortion.
In addition to technical and scientific subsides, this study emphasizes the influence of individual perceptions, feelings and ethical behavior of nursing professionals regarding the development of actions to adequately plan, manage and care for each woman who has experienced an abortion.

\section{REFERENCES}

1. Domingos SRF, Merhigui MAB. O aborto como causa de mortalidade materna: um pensar para o cuidado de enfermagem. Esc Anna Nery Rev Enferm. 2010; 14(1):177-81.

2. Victora CG, Aquino EML, Leal MdC, Monteiro CA, Barros FC, Szwarcwald CL. Maternal and child health in Brazil: progress and challenges. Lancet [online]. 2011 May 28 [acesso 2013 Maio 18]; 377(9780):1863-76. Disponível em: http:// www.sciencedirect.com/science/article/pii/ S0140673611601384

3. Unfpa, Relatório sobre a situação da população mundial 2012. Por escolha, não por acaso: Planejamento Familiar, Direitos Humanos e Desenvolvimento; 2012 [acesso 2013 Mai 22]. Disponível em: www.un.cv/files/BOOK_ SWOP_2012.pdf.pdf

4. Singh S, Darroch J. Adding it Up: Costs and benefits of contraceptive services-estimates for 2012. Nova York (US): Guttmacher Institute e Fundo de População das Nações Unidas; 2012.

5. Mortari CLH, Martini JG, Vargas MA. Representações de enfermeiras sobre o cuidado com mulheres em situação de aborto inseguro. Rev Esc Enferm USP. 2012; 46(4):914-21.

6. Ministério da Saúde (BR). Secretaria de Atenção à Saúde. Área Técnica de Saúde da Mulher. Departamento de Ações Programáticas Estratégicas. Atenção Humanizada ao Abortamento: Norma Técnica, $2^{a}$ ed. Brasília (DF): Ministério da Saúde; 2011.

7. Santos MC, Bernardes A. Comunicação da equipe de enfermagem e a relação com a gerência nas instituições de saúde. Rev Gaúcha Enferm. 2010; 31(2):359-66

8. Christovam BP, Porto IS, Oliveira DC. Gerência do cuidado de enfermagem em cenários hospitalares: a construção de um conceito. Rev Esc Enferm USP. 2012; 46(3):734-41.

9. Gesteira SMA, Diniz NMF, Oliveira EM. Assistência à mulher em processo de abortamento provocado: discurso dos profissionais de enfermagem. Acta Paul Enferm. 2008; 21(3):449-53.

10. Aquino EML, Menezes G, Barreto-de-Araújo TV, Alves MT, Alves S, Valongueiro AMCC. Qualidade da atenção ao aborto no Sistema Único de Saúde do Nordeste brasileiro: o que dizem as mulheres? Ciênc Saúde Coletiva. 2012; 17(7):1765-76. 
11. Bazotti KD, Stumm EMF, Kirchner RM. Ser cuidada por profissionais da saúde: percepções e sentimentos de mulheres que sofreram abortamento. Texto Contexto Enferm. 2009; 18(1):147-54.

12. Mariutti MG, Almeida, AM, Panobianco MS. Nursing care according to women in abortion situations. Rev Latino-Am Enfermagem. 2007; 15(1):20-6.

13. Minayo MCS. O desafio do conhecimento: pesquisa qualitativa em saúde. $10^{\mathrm{a}}$ ed. São Paulo (SP): Hubitec-Abrasco; 2008.

14. Lefèvre F, Lefèvre AMC. O Discurso do sujeito coletivo: um novo enfoque em pesquisa qualitativa (desdobramentos). $2^{\mathrm{a}}$ ed. Caxias do Sul (RS): Educs; 2005.

15. Strefling ISS, Vasconcellos FC. A ética na enfermagem frente às situações de abortamento: uma revisão integrativa da literatura [trabalho de conclusão de curso]. Pelotas (RS): Universidade Católica de Pelotas; 2010.

16. Benute GR, Nonnenmacher D, Nomura RM, Lucia MC, Zugaib M. Perception influence of professionals regarding unsafe in attention to women's health. Rev Bras Ginecol Obstet. 2012; 34(2):69-73.

17. Domingos SRF, Merighi MAB, Jesus MCP. Vivência e cuidado no abortamento espontâneo: um estudo qualitativo. Online Braz J Nurs [online]. 2011 [acesso 2013 Abr 29]; 10(2). Disponível em: http:/ / www.objnursing.uff.br/index.php/nursing/ article/view/3236/htmlhttp://www.objnursing. uff.br/index.php/nursing/article/view/3236/ html_1http://www.objnursing.uff.br/index.php/ nursing/article/view/3236/html_2

18. Souza ZCSN, Diniz NMF. Aborto provocado: o discurso das mulheres sobre suas relações familiares. Texto Contexto Enferm. 2011; 20(4):742-30.

19. Backes DS, Backes MS, Sousa FGM, Erdmann AL. O papel do enfermeiro no contexto hospitalar: a visão de profissionais de saúde. Ciênc Cuidado Saúde. 2008; 7(3):319-26.

20. Swanson KM, Chen HT, Graham JC, Wojnar DM, Petras AJ. Resolution of depression and grief during the first year after miscarriage: a randomized controlled clinical trial of couplesfocused interventions. J Womens Health (Larchmt). 2009; 18(8):1245-57.

21. Mulens RI. Análisis de los cuidados de enfermería ante las respuestas humanas en el aborto espontáneo. Rev Haban Cienc Méd [online]. 2009 [acesso 2013 Abr 29]; 8(3). Disponível em: http:/ / scielo.sld.cu/scielo.php? script $=$ sci arttext\&pid=S1729519X2009000300019\&lng= es\&nrm $=$ iso 